\title{
Marketing Management Of Msme Products, Serang City Groups of Era New Normal
}

Mohamad Fasyehhudin ${ }^{1 *}$,Belardo Prasetya Mega Jaya ${ }^{2}$,Jefry Winter Luhut Hasudungan $^{3}$, Erika Febriani ${ }^{4}$, Chelsea Tiara Septiani Malau ${ }^{5}$, Puput Adela ${ }^{6}$, Rio Primus $^{7}$, Raissa Tsabitha ${ }^{8}$, Alvandri Christian Rahmat Gulo ${ }^{9}$, Ridho Pangestu Taufik ${ }^{10}$

$1^{*}, 2,3,4,5,6,7,8,9$ Faculty of Law, University of Sultan Ageng Tirtayasa

${ }^{10}$ Faculty of Economics and Business, University of Sultan Ageng Tirtayasa

fasyehhudin@untirta.ac.id ${ }^{\left.1^{*}\right)}$

\begin{abstract}
Abstrak
Selama masa new normal ini, masing-masing sektor mendapatkan dampaknya masing-masing, seperti mulai pulihnya dan dimulainya kembali pergerakan, salah satunya adalah sektor ekonomi. Dimana para pelaku usaha yang mengambil peranan penting dalam roda perekonomian nasional harus menjadi perhatian dan fokus bagi pemerintah. Berdasarkan hal tersebut kemudian institusi melalui akademisi menggerakkan mahasiswa dalam program Matching Fund untuk melakukan pengabdian pada masyarakat khususnya UMKM di Kota Serang, oleh karena itu dibentuklah kelompok benama Nine Outlet untuk kemudian berfokus mengasah jiwa kewirausahaan terkait Manajemen Pemasaran Produk UMKM Kota Serang secara Berkelompok pada Era New Normal dengan menyepakati beberapa UMKM yaitu Food and Beverage/Kue Balok Imara, Pisang Cokelat Damory, serta Sale Pisang dan Keripik Pisang Ori 72 untuk memasarkan produk tersebut secara berkelompok dengan memanfaatkan teknologi melalui media sosial sebagai alat untuk pemasaran produk, dengan tujuan menjangkau pasar yang lebih luas.
\end{abstract}

Kata kunci: Usaha Mikro Kecil Menengah, Pemasaran, Berkelompok

\begin{abstract}
During this new normal era, each sector gets its own impact, such as starting to recover and the resumption of movement, one of which is the economic sector. Where business actors who take an important role in the wheels of the national economy must be a concern and focus for the government. Based on this, the institution through academics then mobilized students in the Matching Fund program to do community service, especially MSMEs in Serang City, therefore a group called Nine Outlets was formed to then focus on honing the entrepreneurial spirit related to the Marketing Management of MSME Products in Serang City in Groups in the New Era. It is normal to agree on several MSMEs, namely Food and Beverage/Imara Balok Cake, Damory Chocolate Banana, and Sale Pisang and Ori 72 Banana Chips to market these products in groups by utilizing technology through social media as a tool for product marketing, with the aim of reaching a wider market large.
\end{abstract}

Keywords: Micro Small Medium Enterprises, Marketing, Group 


\section{Introduction}

The Covid-19 pandemic that has plagued Indonesia has caused a national economic recession of minus 3.49 percent in the third quarter of 2020 . Covid-19 in addition to affecting the income of large businesses also affects micro, small and medium enterprises (MSMEs) due to weakening power. buying consumers to conventional MSME strategies that are not ready to face the crisis. Local MSMEs should indeed get great attention from various parties, because apart from being able to revive the community's economy, the production process uses sources of agricultural materials and other local materials so that the rotation of farmers or producers of raw materials to producers of finished goods that are ready to be marketed in the community. Marketing of MSMEs is generally also in a limited domestic scope. The availability of local raw materials for small and medium-sized industries is a distinct advantage that allows them to operate efficiently and can also empower local communities so as to improve the welfare of the wider community (Mujanah, 2015).

The phenomenon above shows how important the existence of MSMEs is in creating economic stability through the absorption of labor and people's income, but due to COVID 19 , productivity levels are low so that economic activity becomes paralyzed. This requires a serious handling strategy so that MSMEs can remain productive and generate the economy, especially with marketing strategies that are easily accessible to consumers.

The COVID-19 pandemic has resulted in a slowdown in the economic cycle of people throughout Indonesia so far. Various methods have been developed for the past two years by the government to directly limit community activities, such as Large-Scale Social Restrictions (PSBB) and Physical Distancing to Enforcement of Community Activity Restrictions (PPKM) on a level scale in every region in Indonesia. Many business actors, both large-scale businesses and micro-enterprises, have their stability shaken, and not a few businesses have gone out of business because they do not able to produce again because of the small number of requests compared to production costs so that business actors give up on perceived losses. However, not all business actors, especially MSMEs, have gone out of business due to the pandemic. There are still many who are trying to survive by utilizing digital media as a tool for marketing their products, then finally this condition affects the business model where it changes from conventional to digitalization by changing the buying and selling model by utilizing technology as a business tool to survive in marketing their products. This is in accordance with Kartajaya (2009), that the internet is an effective solution to attract and strengthen consumer communication.

After a period of time, the government began to feel the urgency for an economic revival so that all Indonesian people could survive in the midst of a pandemic. New Normal with the aim of slowly normalizing every aspect of people's lives, including health, education, and the economy. Strengthening marketing and processing strategies in an innovative manner while maintaining the health protocols set in the era new normal It is absolutely necessary for MSME business actors.

Many MSMEs in Serang City are seriously experiencing problems with selling and marketing products in the current new normal, both in the clothing, accessories, as well as culinary. In improving marketing strategies, it really requires progressive innovation in order to help MSMEs, in this case then the role of student functions is needed, namely as agents of change, social agents, and the next generation who have a special responsibility to blend in with the community and become a means to provide innovative solutions. The focus of the discussion by this group namedNine Outlets are several MSMEs that have been 
mutually agreed upon by the group to be marketed massively both online and offline,

including Imara Balok Cake, Damory Chocolate Banana, and also several products from Ori 72 MSMEs such as Pisang Sale, and Banana Chips.

The purpose of writing this article is to explain what can be shared through these service activities regarding Management Marketing of Serang City MSME Products in Groups in the Era New Normal (Case Study of Group 9 Matching Fund Untirta in Serang City) is also expected to be knowledge for readers and also writers in utilizing technology in groups to market MSME products widely.

\section{Implementation Method}

The activity carried out is the Matching Fund program for the Merdeka Campus Learning Intellectual Property Engineering 2021 for MSME actors and also students to develop superior and effective marketing plans and provide product marketing information online and offline. MSME actors are expected to be able to face the challenges of the business world and be able to develop a careful planning strategy when selling their products so that profits continue to grow during the pandemic. Business actors are also given marketing information that is done online using a website-based application so that the wider community can build a website-based buying and selling business online in order to reach a wider market.

The approach method used in this service is Participatory Action Research (PAR). Where this research involves MSME actors and also the community directly or indirectly in order to achieve the targets in the program. The subject of this research is Micro, Small and Medium Enterprises (UMKM) Imarafood and beverage/lmara Balok Cake, Damory Chocolate Banana MSME, and Ori 72 MSME with Sale Banana and Banana Chips products.

This activity was carried out in Serang City, Banten Province online and offline with entrepreneurs of MSME business. Community service activities will be held on November 5, 2021 - December 5, 2021. Participants in this activity are MSMEs with a total of 8-9 people who are divided into 9 groups.

\section{Result and Discussion}

\section{A. Effectiveness of Marketing Through Social Media}

Digital technology is growing day by day, and there are many ways to individuals or businesses to use digital technology to introduce and promote their products for immediate sale. Digital technology has changed the way people communicate, act and make decisions. ${ }^{1}$ Marketing activities, where everything happens only through individual buying and selling, cannot be separated and now sellers and buyers no longer have to meet, of course all of this cannot be separated from the role of digital technology which makes it easier for business actors to introduce products, introduce brands, get consumers to buy and sell. build consumer confidence more broadly. Of course, digital marketing will be very useful in the MSME business because it can increase sales and increase products on the market.

In the modern era, everyone knows today's social networks. There are various social

\footnotetext{
${ }^{1}$ D. Purwana, R. Rahmi, and S. Aditya, "Pemanfaatan Digital Marketing Bagi Usaha Mikro, Kecil, Dan Menengah (UMKM) Di Kelurahan Malaka Sari, Duren Sawit," J. Pemberdaya. Masy. Madani, vol. 1, no. 1, pp. 1-17, 2017, doi: 10.21009/jpmm.001.1.01.
} 
networks that are widely used, and in addition to supporting communication, social networks are useful for knowing interesting places, beautiful places, selling goods or products, and promoting MSME products or merchandise. The advent of social media is one way that small businesses can scale their business and expand their market at a lower cost. ${ }^{2}$ Of course, it takes creativity and perseverance to attract consumers to buy products or products on sale by small and medium businesses. ${ }^{3}$ Content in various formats, text or scripts, images, video, audio or a combination thereof is converted into digital form so that the resulting content can be read and shared easily through digital media platforms such as laptops, tablets, and even smartphones. ${ }^{4}$ For example to attract consumers, we all know that Instagram and Tiktok, these two social networks are no stranger, with these two social networks, both of which are widely used by users, from teenagers to adults or the elderly. In the features offered by Instagram and Tiktok, MSME business people can channel their creativity through photos or videos to attract buyers or consumers, in one photo, MSME business people can give different styles to the products in the photo, by adding decorations and then modifying them, to make them attractive and pleasing to the eye. In addition, along with the development of digital- based MSMEs, MSME actors must be able to interact with netizens by displaying creative content. ${ }^{5}$

As has been explained how the benefits and usability of social media are very influential for marketing management globally and very quickly, the group Nine Outlets also use social media as a tool to reach the consumer market. The following is an example of marketing through social media Instagram.

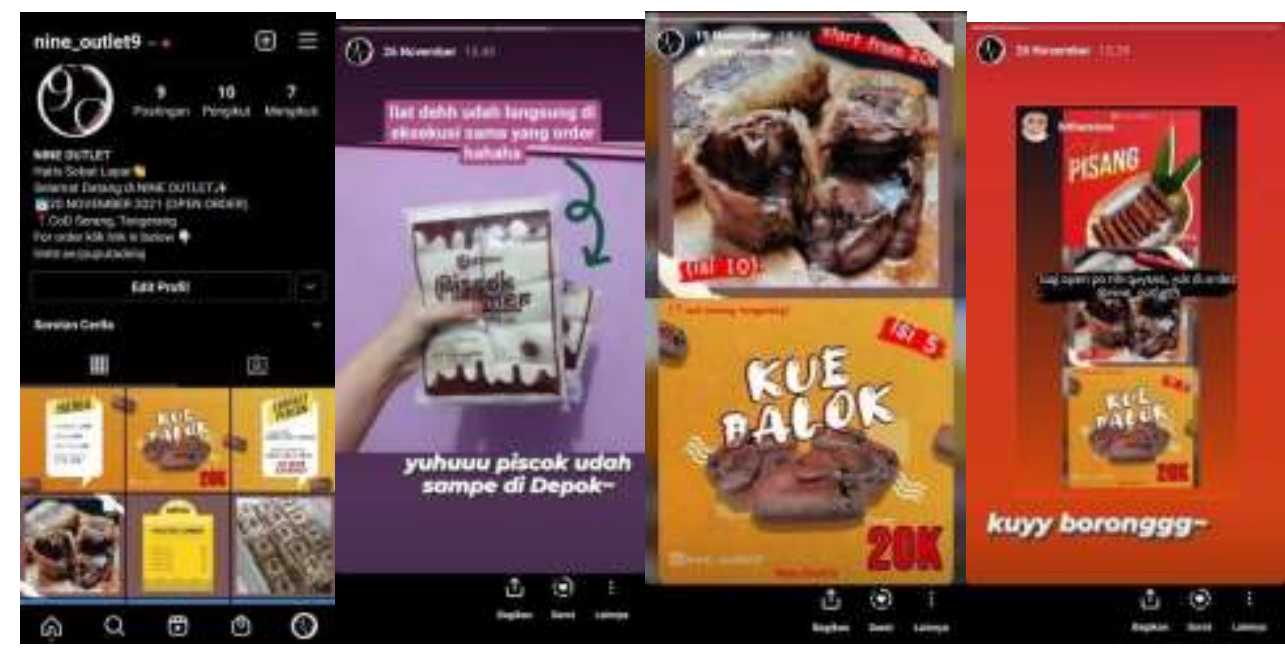

Figure 1. Instagram of Nine Outlets

Instagram is one of the social media that has the most users in Indonesia. With an easy-to-understand display and many interesting features provided by Instagram, making it an opportunity for product marketing. This is also a concern for the groupnine outlets make

\footnotetext{
${ }^{2}$ S. H. Situmorang, H. Mulyono, and L. T. Berampu, "Peran dan Manfaat Sosial Media Marketing bagi Usaha Kecil," AJEFB - Asian J. Entrep. Fam. Bus., vol. 1, no. 2, pp. 77-84, 2018.

${ }^{3}$ S. H. Situmorang, H. Mulyono, and L. T. Berampu, "Peran dan Manfaat Sosial Media Marketing bagi Usaha Kecil," AJEFB - Asian J. Entrep. Fam. Bus., vol. 1, no. 2, pp. 77-84, 2018.

${ }^{4}$ Supangat, "Pertemuan Keempat - Digital Content." 2020

${ }^{5}$ B. Arianto, "Pengembangan UMKM Digital di Masa Pandemi Covid-19," ATRABIS J. Adm. Bisnis, vol. 6, no. 2, pp. 233-247, 2020.
} 
use of media Instagram to create a special account that is https://www.instagram.com/nine outlet9/ for the smooth marketing promotion of cake blocks, melted chocolate bananas, and also banana sales. Consciously by studying product marketing management, especially MSME products in Serang City with the help of social media in the era ofnew normal This really raises our awareness as students that the entrepreneurial spirit can be grown if we are willing and try to keep learning.

\section{B. Forms of MSME Product Marketing Activities in Groups Activities that have been carried out}

The Matching Fund 2021 program is the first program held at Untirta with the theme "Implementation of Intellectual Property Engineering in SMEs/ IKM Assisted by Banten Province in Realizing the Acceleration of the Independent Learning Program-Independent Campus", this program consists of 4 types of activities:

1) SME/IKM Empowerment (Identification of SME/IKM Business Development Constraints, SME/IKM Business Development Clustering, and SME/IKM Development)

2) Business Innovation (Halal Assurance System Training, GKM Training, Shelf Life Product Training, Assistance in Making HKI)

3) Digital Technology (Training System Coding Products, Marketing Digitization Training)

4) Entrepreneurship Culture Development (Capabilities Improvement TOT, Start UP Raw Materials, Launching Young Entrepreneurs)

This activity begins with first socialization with MSMEs and lecturers and related parties, and the last activity is Launching Young Entrepreneurs related to Community Service where 1 group chooses SMEs to be used as a place for entrepreneurship to resell SME / Reseller products, Group 9 Nine Outlets chose Imara Balok Cake, Damory Chocolate Banana, and also some products from MSME Ori 72 such as Banana Sale, and Banana Chips. Our group marketing online via social media like Instagram https://www.instagram.com/nine outlet9/ and a direct approach to the community, each sale using a system pre order.

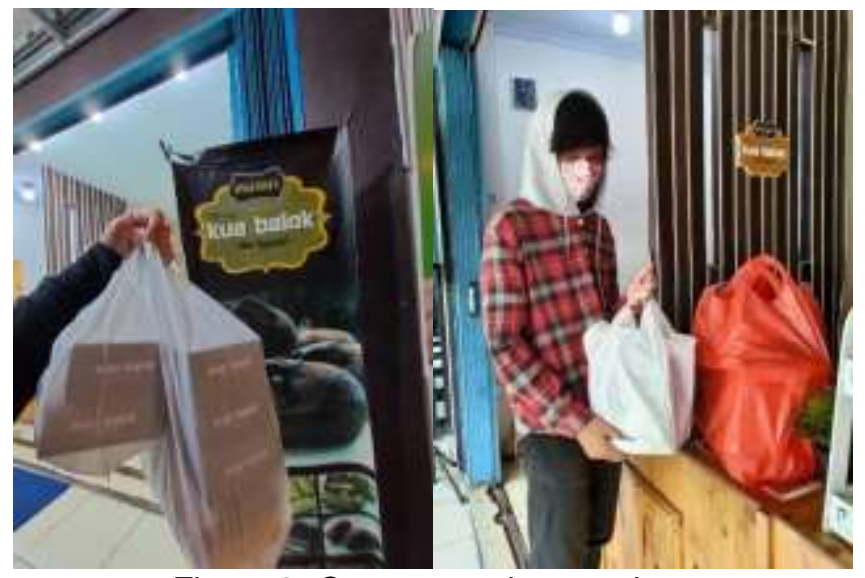

Figure 2. Customer takes products

The picture above is an example when taking product orders directly to the related MSMEs carried out by customers of nine outlets, the product will be ready to be forwarded 
to the customer when the number of orders has reached the target number or has reached the deadline open order which is determined.

\section{Before and During Community Service Activities}

The types of products marketed by the nine outlets group are 3 kinds of flavors (chocolate, cheese, durian, and palm sugar coffee) Imara block cake products, Damory melted chocolate bananas, as well as sale bananas and banana chips produced by SMEs Ori 72. Before carrying out this service activity Nine Outlet prepares whatever is needed for smooth service so that later the positive impact can be felt by MSMEs and us as students to the maximum and real. The things discussed to agree to be implemented are the marketing concepts, sales systems, sales prices, and so on that are needed.

Carrying the concept of "tree roots" which means that each member tries personally to market the product with the hope that it will reach a wider market, not only Serang City but also Tangerang City, Jakarta and surrounding areas. Marketing system This is done by utilizing social media technology such as Instagram by creating a special Nine Outlet account for sales and promotions that are simultaneously distributed massively via WhatsApp or others according to the creativity of each member in a way that can attract potential customers.

The sales system applied is: Pre order where this system is considered effective and efficient for Nine Outlets because as a marketing and sales driver can determine for themselves the number of products sold according to the number of market demands so that there are no remaining products and do not cause losses, product retrieval is done directly by visiting the related MSMEs and then payments can be made conventionally such as COD (Cash On Delivery) This means that payment is made when the product is delivered or in short, payment is made on the spot or by payment online such as through a digital wallet (DANA, OVO, SHOPEEPAY, and Bank Transfer). This kind of marketing and payment system is friendly to the health protocols of the timesnew normal which must still be done because of the lack of direct contact with many people.

In the following, we provide examples of pictures of the products sold during the service period nine outlets, namely cake blocks, melted chocolate banana, and banana sale.

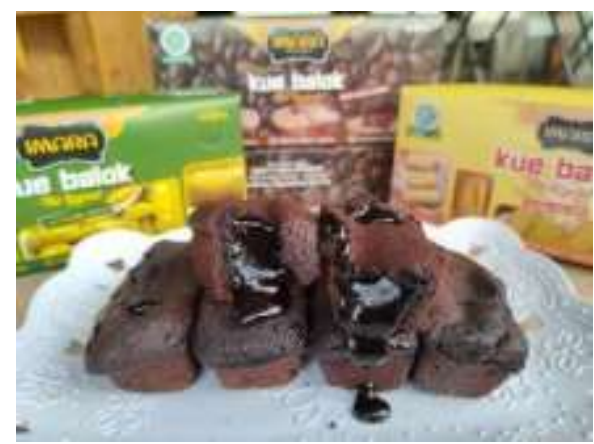

Figure 3. Imara Balok Cake
Imara Balok Cake produced by SMEs IMARA Food and Beverage it has 4 types of flavors, namely chocolate and is the mainstay flavor that is always in demand, then cheese, then durian, and coffee flavored Palm sugar. Various flavors are provided by MSMEs and are prepared to order. 


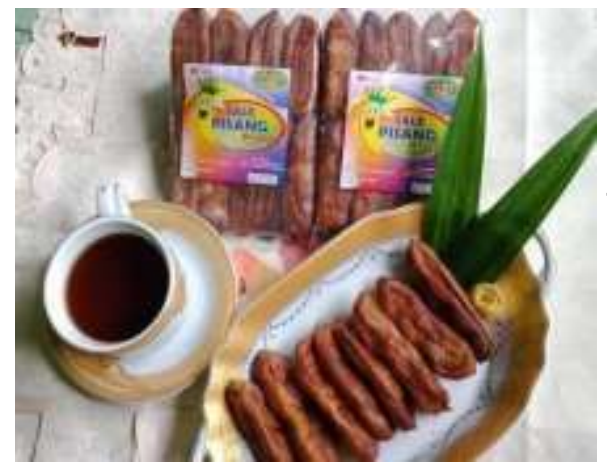

The sale of smoked bananas with the Ori 72 brand has a unique taste in every bite, the smoked bananas turn black to make the pure sweet taste of the bananas authentic and attractive. This product also becomes one of the typical Banten souvenirs that can be brought home.

Figure 4. Sale of smoked bananas

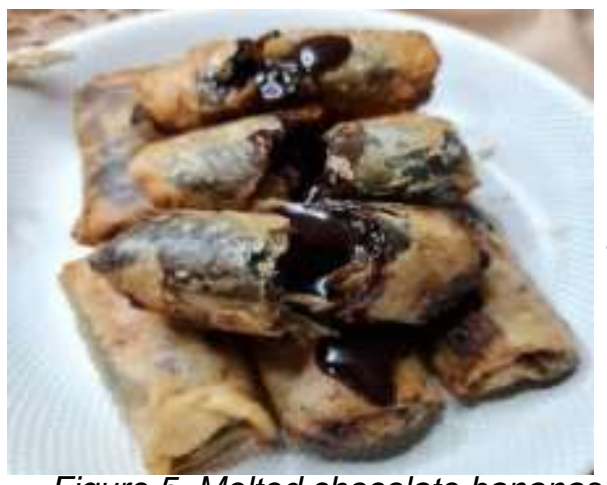

Melted chocolate bananas typical of Damory SMEs are marketed in the form of frozen food. An advantage because these chocolate bananas can be enjoyed anytime and can be stored in the freezer for months. Of course, there is nothing to lose when buying in large quantities.

Figure 5. Melted chocolate bananas

\section{After Community Service Activities}

This Community Service activity aims to assist MSMEs involved with the Matching Fund program and also as a direct learning platform for students to learn not only course theory but also to learn directly by participating directly in MSME business actors regarding entrepreneurship regarding MSME development. through marketing management to financial management.

After completing the service period for the given time of approximately one month, a lot of knowledge was obtained not only about entrepreneurship but also had the opportunity to help MSME parties who were constrained by intellectual property such as copyrights, brand rights, patents, or graphic/logo designs, as well as marketing through social media. With the knowledge gained, then to become output for each student, namely by making journal articles that contain knowledge and knowledge gained during service activities and students are able to become young entrepreneurs. Which means this program provides many benefits both for entrepreneurs of MSME business and also for college students, of course this knowledge can be developed in the future with the hope that students can develop an entrepreneurial spirit for the future, even the greatest possibility during this period of service can be continued together. 
The following is attached a picture of the marketing and product sales carried out by the team nine outlets.
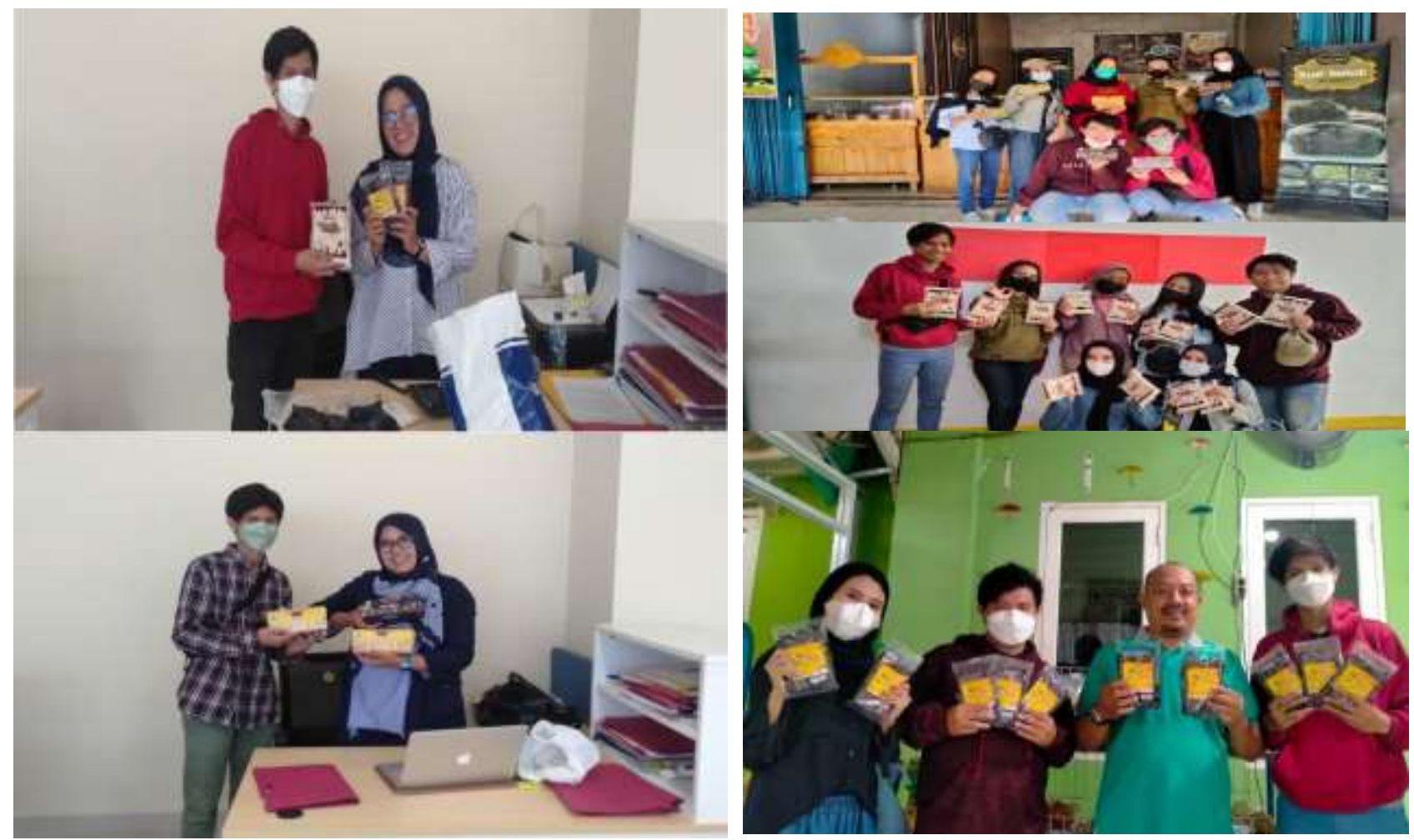

Figure 6. Entrepreneurial Culture Exposure I

When the specified service period is completed for approximately one month, then the program Matching Fund through a team consisting of lecturers brought back the "Entrepreneurial Culture Exposure" activity where the activity was carried out offline at the law faculty of Sultan Ageng Tirtayasa University on December 16, 2021.

This exposure to entrepreneurial culture presents dozens of MSME products in Banten Province through students who are members of the program Matching Fund to be exhibited and sold directly with the system bazaar which was attended by campus officials and other campus residents. This activity also trains all students who joining the Matching Fund for entrepreneurship directly without going through digital, this also trains the courage of students to do direct marketing and promotion with their respective concepts and methods. GroupNine Outlets also participated in this activity with great enthusiasm and decorated stand maximally but still maintain the Health protocol. 
Here are some group documentation Nine Outlets in Entrepreneurship Culture Expose Activities.

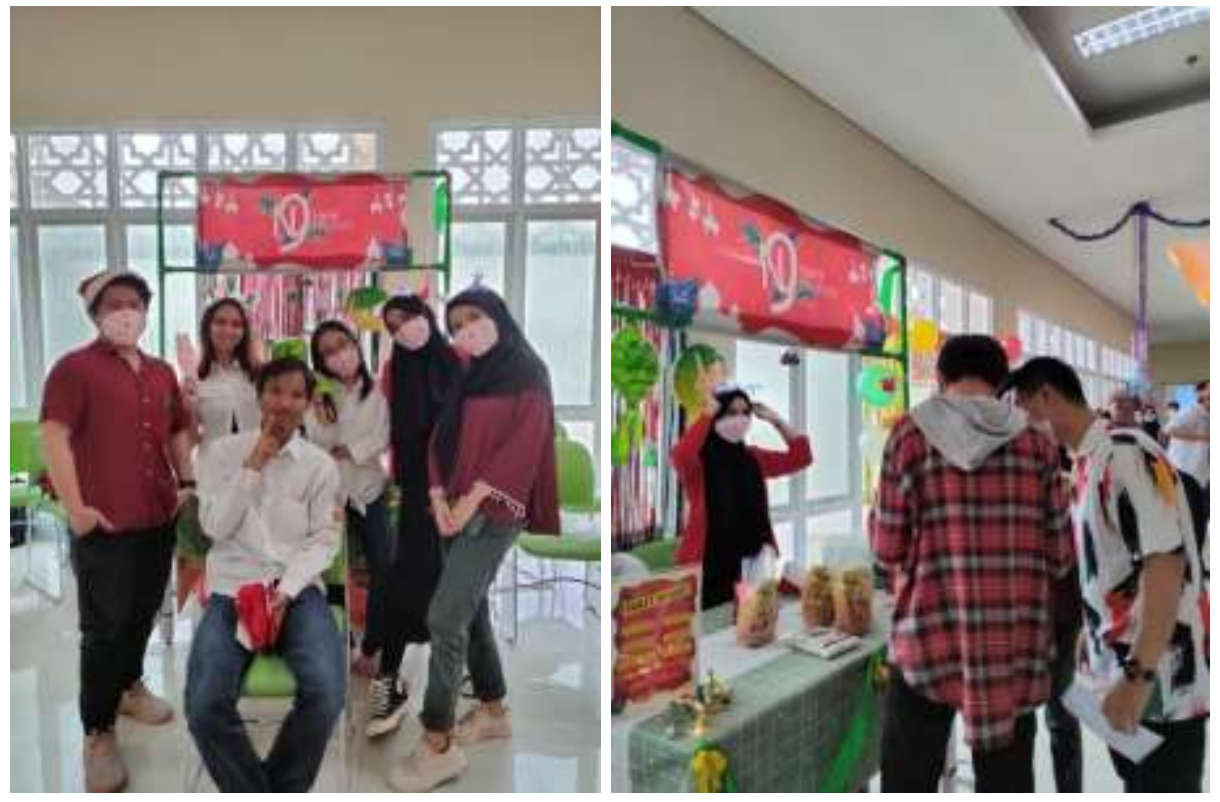

Figure 7. Entrepreneurial Culture Exposure II

With the end of the entrepreneurship culture exposure activity, the Matching Fund program ended, but with the knowledge and invaluable experience gained, it is hoped that students who join, especially the Nine Outlet team, can apply their entrepreneurial knowledge to the fullest and can even become young entrepreneurs who are able to bring development for the economy in Indonesia.

\section{Conclusion}

The COVID-19 pandemic period which lasted approximately 2 (two) years in Indonesia caused an economic crisis in the early years, namely in 2019 to 2020, of course, it could have a huge impact on the business sector, both large-scale and MSME scale. However, at this time the economic sector is starting to rise and move again because of the era of globalization new normal have been implemented and new living habits by implementing health protocols when carrying out daily activities as usual, conditions like this are able to slowly return to life.

The economic impact is felt by all business actors, especially MSMEs in Indonesia, many of which are at a loss and decide to go out of business due to limited production costs that must be met even though market demand is very thin, not infrequently there is no market demand. Local MSMEs who have limitations in marketing eranew normal Of course, taking advantage of this technological development needs to be a concern and focus for the government and the responsible parties.

One of the cities in Banten Province, namely Serang, also felt the same impact, experienced serious problems related to marketing and sales, a lot of MSMEs complained about this but there had been no significant changes to improve the production process. Then this is a concern for institutional academics to create a program that can help MSME parties by mobilizing students as direct agents to directly assist what is needed. This attention is then channeled through the holding of a program MATCHING FUND as a 
period of student service by involving dozens of MSMEs in Serang City, Serang Regency, and Cilegon City

With this useful program, it becomes a means to share knowledge between MSMEs and students. It is hoped that through this program, it can help MSMEs continuously and for students to apply entrepreneurship knowledge well because they have learned directly.

\section{References}

Andreas Andrie Djatmiko, Bayu Cahyoadi, "Penguatan Strategi Pemasaran Dan Pengolahan Produk Secara Inovatif Sebagai Optimalisasi Eksistensi Bumdes Dan Pelaku Umkm Di Era New Normal," J-ADIMAS, Volume 8, Nomor 2, Desember 2020: $96-106$.

B. Arianto, "Pengembangan UMKM Digital di Masa Pandemi Covid-19," ATRABIS J. Adm. Bisnis, vol. 6, no. 2, pp. 233-247, 2020.

D. Purwana, R. Rahmi, and S. Aditya, "Pemanfaatan Digital Marketing Bagi Usaha Mikro, Kecil, Dan Menengah (UMKM) Di Kelurahan Malaka Sari, Duren Sawit," J. Pemberdaya.Masy.Madani,vol.1,no.1,pp.1-17,2017,doi:10.21009/jpmm.001.1.01.

Ginting Mulianta Ari dkk, 2017. Strategi Pengembangan Ekonomi Kreatif di Indonesia, Yayasan Pustaka Obor Indonesia, Cetakan 1.

Lili Marlinah, 2020. Peluang dan Tantangan UMKM Dalam Upaya Memperkuat Perekonomian Nasional Tahun 2020 Ditengah Pandemi Covid 19, Jurnal Ekonomi, Volume 22 Nomor 2.

Nardi Sunardi, dkk, 2020. Peran Manajemen Keuangan dan Digital Marketing dalam Upaya Peningkatan Omset Penjualan bagi UMKM Pasar Modern Intermoda BSD City Kota Tangerang Selatan di Tengah Pandemi Covid-19. Jurnal Abdimas Humanis Vol 2 No 1.

Rahardjo Tri Weda, dkk,2019. Strategi Pemasaran dan daya Saing UMKM berbasis Kemitraan. Jakarta, Salemba Empat

Rifzaldi Nasri1,Nuraeni, and Dina Febriani Darmansyah, "Pelatihan Marketing Digital Di Masa Pandemi Pada Umkm Binaan Bmt Umj," http://jurnal.umj.ac.id/index.php/semnaskat.

S. H. Situmorang, H. Mulyono, and L. T. Berampu, "Peran dan Manfaat Sosial Media Marketing bagi Usaha Kecil," AJEFB - Asian J. Entrep. Fam. Bus., vol. 1, no. 2, pp. 77-84, 2018.

Supangat, "Pertemuan Keempat - Digital Content." 2020. 